\title{
Performance Analysis of Data Mining Methods for Sexually Transmitted Disease Classification
}

\author{
Gusti E. Yuliastuti, Adyan N. Alfiyatin, Agung M. Rizki, A. Hamdianah, H. Taufiq, \\ W. F. Mahmudy \\ Faculty of Computer Science, Brawijaya University, Malang, Indonesia
}

\begin{tabular}{l}
\hline \hline Article Info \\
\hline Article history: \\
Received Jun 5, 2018 \\
Revised Sep 15, 2018 \\
Accepted Sep 22, 2018 \\
\hline Keyword: \\
Classification task \\
Data mining \\
K-means \\
K-nearest neighbor \\
Naïve bayes \\
Sexually transmitted disease \\
\hline
\end{tabular}

\begin{abstract}
According to health reports of Malang city, many people are exposed to sexually transmitted diseases and most sufferers are not aware of the symptoms. Malang city being known as a city of education so that every year the population number increases, it is at risk of increasing the spread of sexually transmitted diseases virus. This problem is important to be solved to treat earlier sufferers sexually transmitted diseases virus in order to reduce the burden of patient spending. In this research, authors conduct data mining methods to classifying sexually transmitted diseases. From the experiment result shows that $\mathrm{K}-\mathrm{NN}$ is the best method for solve this problem with $90 \%$ accuracy.
\end{abstract}

Copyright $@ 2018$ Institute of Advanced Engineering and Science. All rights reserved.

\section{Corresponding Author:}

Wayan Firdaus Mahmudy,

Faculty of Computer Science,

Brawijaya University,

Veteran Road 8, Malang 65145, Indonesia.

Email: wayanfm@ub.ac.id

\section{INTRODUCTION}

Sexually Transmitted Infections (STI) are Sexually Transmitted Disease (STD), both with infected partners and those who frequently alternate partners [1]. More than 30 different bacterias, viruses and parasites that can be transmitted by sexual intercourse. In STD there are 8 frequent infections of 8 infections with these newly curable $50 \%$ syphilis, gonorrhoea, chlamydia and trichomoniasis. The other $50 \%$ that cannot be cured include hepatitis B, HSV (Herpes Simplex Virus) or herpes, HIV, HPV (Human Papillomavirus) [2].

In Indonesia, especially in the Malang city, the number of people with HIV / AIDS in 2014 as many as 466 people, AIDS reach 225 people, syphilis 14 people [3]. According to a Malang city health report the average patient aged 25-49 years [3]. Some STD occur asymptomatic [2]. Asymptomatic is a disease when the patient is not aware of any symptoms. Asymptomatic may not be detected until the patient performs a medical test. The Malang city is growing every year, both in social, demographic, and population migration [4]. Besides being known as a tourist destination, Malang city also known as a city of education so that every year the population number increases [3], [5], it is at risk of increasing the spread of STD virus. Treatment when infected with STD virus requires much cost [1]. Therefore, it is important to treat earlier sufferers STD virus in order to reduce the burden of patient spending.

Along with technological developments in this modern era detect STD can utilize information technology. One way is to build a system that can help patients to detect STD early and treat individually [6]. Some previous studies have been conducted by Lakshmi and Isakki [7] about comparing several methods in data mining such as Decision Tree, Support Vector Machine (SVM), Naïve Bayes for predicting HIV / AIDS disease. The results of the study showed that Decision Tree received the highest accuracy of $90.0741 \%$, then 
SVM with $85.05 \%$ and lowest Naïve Bayes with $77.5 \%$ accuracy. The second study was conducted by Dangare and Apte [6] on cardiovascular prediction systems using a comparison of 3 methods: Neural Network, Decision Tree And Naïve Bayes. The conclusion from the research is that by using Neural Network method on detection of heart disease get $100 \%$ accuracy means that between original data and computer result have no bias. Subsequent research on the prediction of anti-retroviral drug consumption based on previous consumer drug data on pharmacy at Jugal hospital [8] using M5P tree model got the best result. Subsequent research was conducted by Kaur and Bawa [9] on suitable methods in predicting various diseases and the results of his research stated that the Decision Tree method obtained an accuracy of $95 \%$. There are some previous studies relevant to this issue, further to be discussed more clearly in the literature studies.

This issue is important to solve because the disease is very dangerous and will be fateful if not treated immediately as soon as possible. Therefore, this research will classify STD diseases based on existing symptoms with future goals if there is a new symptom can be detected early disease. Author will focus on testing the accuracy of three data mining methods which are Naïve Bayes, K-Means and K-Nearest Neighbor (K-NN) against the STD disease classification in addition to testing research methods also aimed at early detection of STD. So, in the final conclusion we will get the best method for classifying STD.

\section{LITERATURE STUDY}

Data mining is also called knowledge discovery in database [10]. The problem of classification of diseases like this can be said included in the data mining case because it requires the existence of knowledge before it can be classified. A lot of methods in data mining that can be used, but in this research the authors focus to compare three methods namely Naïve Bayes, K-Means and K-NN.

The Naïve Bayes method can be applied to solve classification problems as in previous studies. Patil et al., [11] applied the Naïve Bayesand J4.8 Decision Tree methods in classifying data. Then from both methods compared to their performance and based on the results of the experiment it can be concluded that the Naïve BayesMethod is more efficient. Durgalakshmi et al., [12] implemented an improved version of the Naïve Bayesmethod for classifying breast cannabis diseases. The improved version of the Naïve Bayesmethod lies in its performance and accuracy calculations. In contrast, Griffis et al., [13] adopted an automated approach to identify stroke by using the Naïve Bayes method. While Lakoumentas et al., [14] optimized the method of Naive Bayesin the classification of B-Chronic Lymphocytic Leukemia (B-CLL) disease. The difference with conventional Naïve Bayesmethods lies in attributes when classifying discrete values and optimizing their accuracy values.

In addition to the method of Naïve Bayes, can also do the classification by using K-Means method. Cimen et al., [15] applied the K-Means method to classify Arrhythmia based on Conic's olyhedral function algorithm. The performance test results are shown through numerical experiments, while the accuracy is 98\%. Khanmohammadi [16] improvised the K-Means method for medical applications. Improvisation is done by using overlapping technique, which is a technique derived from conventional method K-Means. Overlapping K-Means (OKM) is considered to be efficient in classifying data for medical applications. Anand [17] detected plant diseases in the Brinjal leaves through image processing techniques. In the process of detecting the image, the researcher uses K-Means method for segmentation and Neural Network method for classification. There is a renewal framework for classifying symptoms of Syncope disease. Using the KMeans method, Guftar [18] predicts the major causes that can cause Syncope's disease. The results of his experiments were compared with other methods such as K-Means fast, K-Medoids and X-Means. While Santhanam et al., [19] combines three methods at once namely the method of K-Means, Genetic Algorithm and Support Vector Machines (SVM) to diagnose diabetes. The K-Means method is used to eliminate noisy data, Genetic Algorithms are used to find optimal features whereas SVM is used for classification. From the results of the experiment obtained an accuracy of $96.71 \%$.

Udovychenko et al., [20] classifies heart failure by using K-NN Binary. From the experiment results obtained $80-88 \%$ accuracy range, $70-95 \%$ sensitivity, 78-95\% specification and $77-93 \%$ precision. In another research, Udovychenko et al., [21] classified the Ischemic heartbeat using the K-Means method. Based on the results of the experiment, the optimal number of neighbors in increasing accuracy was 20-25 neighbors. Another case with Saha et al., [22] classified gene selection using K-NN and other heuristic methods. The $\mathrm{K}-\mathrm{NN}$ method is used to classify the example. While the heuristic method chosen is Simulated Annealing (SA) and Particle Swarm Optimization (PSO). Based on the results of the experiment, researchers claim that the SA method is better than the PSO.

Based on some previous studies that apply any methods with their advantages. So, the authors will perform accuracy analysis of three data mining methods in classifying sexually transmitted diseases. The three methods are Naïve Bayes, K-Means and K-NN. 


\section{SEXUALLY TRANSMITTED DISEASE}

Sexually Transmitted Disease (STD) is a disease that is transmitted from one person to another through sexual contact. As a result of STD the occurrence of reproductive tract infections so that if not treated immediately the infection will cause patients with prolonged illness, infertility and death. Symptoms of STD include secretion or pus from the penis, vagina or anus, the onset of pain or feeling of heat during urination, the presence of lumps, nodules or wounds on the penis, vagina, anus or mouth, the occurrence of swelling in the thighs, the occurrence of bleeding after sex, The onset of pain in the lower abdomen (woman) and pain in the testicles. Some type of STD can be seen in Table 1.

Table 1. Type of Sexually Transmitted Disease

\begin{tabular}{|c|c|c|}
\hline Diseases & Symptoms & Caused by Bacterial \\
\hline Gonorrhoea & $\begin{array}{l}\text { a. Urge to urinate } \\
\text { b. Pain when urinating } \\
\text { c. The discharge of white fluid from the vagina and this spread } \\
\text { can reach the cervix, uterus, fallopian tubes, ovaries, urethra } \\
\text { (lower urinary tract) } \\
\text { d. Pain in the hip or pain during sexual intercourse. }\end{array}$ & Neiseria Gonorrhoeae \\
\hline Syphilis & $\begin{array}{l}\text { a. Symptoms last } 3-4 \text { weeks sometimes up to } 13 \text { weeks later a } \\
\text { lump around the genitals } \\
\text { b. Accompanied by dizziness } \\
\text { c. Bone-like bone pain that will go away without treatment } \\
\text { d. Reddish spots on the body about } 6-12 \text { weeks after intercourse }\end{array}$ & Treponema Pallidium \\
\hline Herpes Genitalis & $\begin{array}{l}\text { Arise for } 1-3 \text { weeks of watery (clotted grape-like) pee in the } \\
\text { vicinity of the genitals, then rupture and leave the wound dry, } \\
\text { then disappear and the symptoms recur again as above but not } \\
\text { senyeri early stage. }\end{array}$ & Herpes Simplex type $2(H S V-2)$ \\
\hline Chlamydia & $\begin{array}{l}\text { a. Arising inflammation of the male and female reproductive } \\
\text { organs } \\
\text { b. Discharge of fluid from genitals or whitish yellowish white } \\
\text { c. Pain in the pelvic cavity and after-sex bleeding }\end{array}$ & Chlamydia \\
\hline Trichomoniasis & a. Dilute vaginal fluid yellowish, foamy and foul-smelling & Trikomonas Vaginalis \\
\hline Vaginalis & $\begin{array}{l}\text { b. Vulva slightly swollen, redness, itching and feel } \\
\text { uncomfortable } \\
\text { c. Pain during intercourse or while urinating }\end{array}$ & \\
\hline Genital Warts & $\begin{array}{l}\text { a. Infected women about the skin of the genital area to the anus, } \\
\text { the mucous membrane inside the genitals to the cervix. } \\
\text { b. Pregnant women infected with warts can grow large, genital } \\
\text { warts can sometimes lead to cervical cancer or skin cancer } \\
\text { around the genitals. } \\
\text { c. Infected men about genital and urinary tract. }\end{array}$ & Human Papiloma Virus \\
\hline Chancroid & $\begin{array}{l}\text { a. There are wounds that fester or acute rot and pain in the } \\
\text { genitals, diameter size less than } 1 \mathrm{~cm} \\
\text { b. The swelling of the sore from the gland. }\end{array}$ & Haemophilus Ducreyl \\
\hline $\begin{array}{l}\text { Limphogranulama } \\
\text { Venereum }\end{array}$ & $\begin{array}{l}\text { A small sore that does not hurt in the genital area and followed } \\
\text { by painful swelling. }\end{array}$ & Chlamydia Trachomatis \\
\hline Granuloma Inguinale & $\begin{array}{l}\text { There is a small cut on the skin of the genitals and will spread to } \\
\text { form a mass of graulomatus (small bumps) that can cause severe } \\
\text { damage to the pubic organs. }\end{array}$ & Donovania Granulomatis \\
\hline Cervicitis & $\begin{array}{l}\text { - Frequent urination } \\
\text { - Pain during urination } \\
\text { - Pain during intercourse } \\
\text { - Abnormal vaginal bleeding } \\
\text { - Vaginal discharge. }\end{array}$ & Bacterial Infections \\
\hline Vaginal Candidiasis & $\begin{array}{l}\text { Itching and irritation of the vagina and vulva (skin folds outside } \\
\text { the vagina) accompanied by a vaginal secret that is white, thick, } \\
\text { resembling cheese. }\end{array}$ & Candida Albicans \\
\hline Bacterial Vaginosis & $\begin{array}{l}\text { - Out dilute liquid, white or gray } \\
\text { - Smell of vagina }\end{array}$ & Polimikroba \\
\hline $\begin{array}{l}\text { Mollusculum } \\
\text { Contagiosum }\end{array}$ & $\begin{array}{l}\text { Occurs in the form of papules (slippery bumps), no pain and can } \\
\text { disappear by itself without treatment }\end{array}$ & Virus Infections \\
\hline Proctitis & Pain in the rectum. & - \\
\hline $\begin{array}{l}\text { Neonatal } \\
\text { Conjunctivitis }\end{array}$ & $\begin{array}{l}\text { An infection of the conjunctiva (the white part of the eye) and } \\
\text { the membrane lining the eyelids. }\end{array}$ & $\begin{array}{l}\text { Streptococcus Pneumoniae, } \\
\text { Hemophilus Influenzae, } \\
\text { Neisseria Gonorrhoeae and } \\
\text { Herpes Symplex Virus }\end{array}$ \\
\hline Pelvic Inflammation & $\begin{array}{l}\text { Inflammation or infection of organs in the female pelvis. The } \\
\text { pelvic organs include the uterus (uterus), fallopian tubes } \\
\text { (oviduct), ovaries, and cervix. }\end{array}$ & - \\
\hline
\end{tabular}




\section{RESEARCH METHOD}

In this research, using 139 sample data from one of hospitals in Malang city. The data consist of 109 testing data and 30 training data. From 109 testing data there are 16 classes of diseases and each disease consists of 29 symptoms. 16 such diseases are Gonorrhoea, Syphilis, Herpes Genitalis, Chlamydia, Trichomoniasis Vaginalis, Genital Warts, Chancroid, Lymphogranuloma Venereum, Granuloma Inguinale, Cervicitis, Vaginal Candidiasis, Bacterial Vaginosis, Mollusculum Contagiosum, Neonatal Conjunctivitis, Proctitis and Pelvic Inflammation. In this research, the authors applied three data mining methods for STD classification. There are Naïve Bayes, K-Means and K-NN. Next will be discussed each methods.

\subsection{Naïve bayes}

Naïve Bayes is a classification method using simple probabilities by computing a set of probabilities and summing the frequency and value combinations of the given dataset [23]. This method assumes all attributes to be independent (not interdependent) given by the value of the class variable [11]. The advantage of Naïve Bayes is that it is easy to construct does not require complicated parameter estimation schemes, it is easy to apply to large data sets, the classification results are easily interpreted by the layman [24]. The equations of Naïve Bayes [25] shown in Equation (1).

$$
P(H \mid X)=\frac{P(X \mid H) \times P(H)}{P(X)}
$$

Where
$X$ : Data with unknown class
$H \quad$ : The data hypothesis is a specific class
$P(H \mid X)$ : The probability of hypothesis $H$ is based on condition $X$ (posteriori probabilities)
$P(H) \quad$ : Probability of hypothesis $H$ (prior probability)
$P(X \mid H)$ : The probability of $X$ is based on the conditions in hypothesis $H$
$P(X) \quad$ : Probability $X$

\subsection{K-means}

K-Means is one of the simple form of unsupervised learning algorithms [26]. K-Means is a method using a centroid model in which the centroid is the midpoint of a cluster and is usually in the form of a value [25]. The function of the centroid to calculate the distance of a data object against the centroid [24]. The K-Means steps are [27]:

a. Initialize, determine the value of $K$ as the cluster. If necessary specify the threshold of the change of objective function (the limit determines the iteration stops) and the threshold of centroid position change.

b. Determining the centroid value of $K$ data from the data set $X$.

c. Calculate the metric distance of the object with the centroid shown in Equation (2).

$$
d_{(a, b)}=\sqrt{\sum_{i=1}^{n}\left(a_{i}-b_{i}\right)^{2}}
$$

Where,

$$
\begin{array}{ll}
d_{(a, b)} & : \text { Distance of object between object } a \text { and } b \\
n & : \text { Dimension of data } \\
a_{i} & : \text { Coordinate of object } a \text { on dimension } n \\
b_{i} & : \text { Coordinate of object } b \text { in dimension } n
\end{array}
$$

d. Classify objects based on the minimum distance of the centroid.

e. Repeat steps 3 and 4 until reaching convergent conditions are reached where the change of objective function is below the threshold or no cluster-shifting data or the centroid position change is below the threshold.

\subsection{K-nearest neighbor}

$\mathrm{K}-\mathrm{NN}$ is a non-parametric classification method [28]. Computationally, it is simpler than other methods. K-NN works by calculating the proximity between a new case and an old case based on matching weights of a number of existing features [25]. Identify with this method based on the similarity with the previous case. Here to calculate the similarity between new cases and old cases with the following Equation (3). 


$$
\operatorname{similarity}(T, S)=\frac{\sum_{i=1}^{n} f\left(T_{i}, S_{i}\right) * w_{i}}{w_{i}}
$$

Where,

$$
\begin{array}{ll}
T & \text { : new case } \\
S & \text { : existing cases in storage } \\
N & \text { : attribute in each case } \\
i & \text { : an individual attribute between } 1 \text { to } n \\
f & \text { : Similarity attribute } I \text { function between case } T \text { and case } S \\
w & \text { : the weights assigned to attribute } i
\end{array}
$$

Proximity usually lies in the value between 0 until 1 . The value 0 means that both cases are absolutely unlike, otherwise for a case value of 1 case is similar to absolute. The K-NN steps are:

a. Determine the parameter $K$ (the number of nearest neighbors)

b. Calculate the square of the Euclidean Distance of each object with the sample data.

c. Sort by the smallest Euclidean distance. Euclidean distance formula shown in Equation (5).

$$
D(x, y)=\sqrt{\sum_{k-1}^{n}(x k-y k)^{2}}=\sqrt{\left(a_{1}-b_{1}\right)^{2}+\left(a_{2}-b_{2}\right)^{2}+\cdots+\left(a_{n}-b_{n}\right)^{2}}
$$

d. Collecting category $Y$ (K-NN classification)

e. Predicting query values by majority category.

\section{EXPERIMENTAL SETUP AND RESULTS}

This experiment using 30 testing data that will be compared with the actual data to find out the accuracy of these methods implementation. Measuring the accuracy using percentage theory shown in Equation (6).

$$
\text { Accuracy }=\frac{\sum \text { correct data }}{\sum \text { testing data }} \times 100 \%
$$

The result of STD classification using that three algortihms shown in Table 2.

Table 2. Result of STD Classification

\begin{tabular}{lcccc}
\hline \multicolumn{1}{c}{ Methods } & Correct & Data & Ancorrect & Accuracy \\
\hline Naïve Bayes & 23 & 7 & $76.67 \%$ \\
K-Means & 3 & 27 & $10 \%$ \\
K-NN & 27 & 3 & $90 \%$ \\
\hline
\end{tabular}

From the results of these experiments, the K-Means method showed the worst results. It can be due to the initialization of $\mathrm{K}$ randomly points, so if the random value is worst then the result of classification becomes less optimal. The result of K-Means method is not optimal also can be due to the value of the parameters of each symptom, which is only two values i.e. 0 and 1 . Instead of fuzzy value whose the value can be more varied, so that more optimal in doing classification. Another factor that can affected is the dimension of data which is in this research using data with 29 dimensions. It cause the K-Means difficult in determining the appropriate $K$ value. K-Means characteristic itself is more suited to clustering problems than classification problems.

Better results obtained with Naïve Bayes method with the result $76.67 \%$ match. This can happen because Naïve Bayes has advantages in dealing with classification problems, especially quantitative data. With relatively little training data, this method is able to get optimal result. This is also supported by the advantages of Naïve Bayes in dealing with missing values as well as stronger attributes that are less relevant.

The best result is obtained by using K-NN method. The K-NN method can produce a more accurate and effective classification than any other method when the training data is large enough as in the experiment. This method is also robust dealing with noise data. In applying these three methods, there are 
some incorrect data in the classification. The occurrence of misclassification is due to the different types of diseases of some of the same symptoms of the patient. For example that is when classifying Scrotal Welling and Bacterial Vaginosis diseases. In the actual data there are some patients with similar symptoms but the type of disease suffered differently. This can make accuracy in doing classification less optimal.

\section{CONCLUSION AND FUTURE WORK}

In this research, authors has done experiment using data mining methods for STD classification using 139 data, 109 as training data and 30 as testing data. The best method for STD classification is K-NN with the highest accurary that is $90 \%$. The accuracy results are quite good, but in the future the authors will conduct research to improve the accuracy of classification results by optimizing parameters of K-NN method that has been done in our previous research for other classification problems [29], [30]. In addition, in the next research will also test the amount of training data and testing data in order to obtain accurate classification results.

\section{ACKNOWLEDGEMENTS} research

The authors would like to thank Ratri Arijaya for his role in collecting data for purposes of this

\section{REFERENCES}

[1] T. Y. Aditama, "Pedoman Nasional Penanganan Infeksi Menular Seksual", Jakarta, Kementrian Kesehatan Republik Indonesia, 2011.

[2] World Health Organization, "Media Centre-Sexually Transmitted Infections (STIs)", 2016. [Online]. Available: http://www.who.int/mediacentre/factsheets/fs110/en/.

[3] Dinas Kesehatan Kota Malang, "Profil Kesehatan Kota Malang Tahun 2014," 2015.

[4] Badan Pusat Statistik, "Proyeksi Penduduk Indonesia 2010-2035," 2015.

[5] Badan Pusat Statistik, "Data Sensus Penduduk"” 2017. [Online]. Available: https://jatim.bps.go.id/linkTabelStatis/view/id/330.

[6] C. S. Dangare and S. S. Apte, "Improved Study of Heart Disease Prediction System using Data Mining Classification Techniques", Int. J. Comput. Appl. (0975 - 888), vol. 47, no. 10, pp. 44-48, 2012.

[7] S. L. D. Isakki, "A Comparative Study of Data Mining Classification Technique Using HIV/AIDS and STD data", Int. J. Innov. Res. Comput. Commun. Eng., vol. 5, no. 1, pp. 134-139, 2017.

[8] P. D. Cerna and T. J. Abdulahi, "Prediction of Anti-Retroviral Drug Consumption for HIV Patient in Hospital Pharmacy using Data Mining Technique”, Int. J. Inf. Technol. Comput. Sci., vol. 8, no. 2, pp. 52-59, 2016.

[9] S. Kaur and R. K. Bawa, "Future Trends of Data Mining in Predicting the Various Diseases in Medical Healthcare System”, Int. J. Energy, Inf. Commun., vol. 6, no. 4, pp. 17-34, 2015.

[10] W. Wiharto, et al., "System Diagnosis of Coronary Heart Disease Using a Combination of Dimensional Reduction and Data Mining Techniques : A Review", Indones. J. Electr. Eng. Comput. Sci., vol. 7, no. 2, pp. 514-523, 2017.

[11] T. R. Patil, "Performance Analysis of Naive Bayes and J48 Classification Algorithm for Data Classification", Int. J. Comput. Sci. Appl., vol. 6, no. 2, pp. 256-261, 2013.

[12] B. Durgalakshmi and V. Vijayakumar, "Progonosis and Modelling of Breast Cancer and Its Growth Novel Naive Bayes”, Procedia Comput. Sci., vol. 50, pp. 551-553, 2015.

[13] J. C. Griffis, et al., "Voxel-based Gaussian Naive Bayes Classification of Ischemic Stroke Lesions in Individual T1-Weighted MRI Scans", J. Neurosci. Methods, vol. 257, pp. 97-108, 2016.

[14] J. Lakoumentas, et al., "Optimizations of the Naïve-Bayes Classifier for the Prognosis of B-Chronic Lymphocytic Leukemia Incorporating Flow Cytometry Data”, Comput. Methods Programs Biomed., vol. 108, no. 1, pp. 158-167, 2012.

[15] E. Cimen and G. Ozturk, "Arrhythmia Classification via k-Means based Polyhedral Conic Functions Algorithm", in International Conference on Computational Science and Computational Intelligence Arrhythmia, 2016.

[16] S. Khanmohammadi, et al., "An Improved Overlapping k-Means Clustering Method for Medical Applications", Expert Syst. Appl., vol. 67, pp. 12-18, 2017.

[17] R. Anand, et al., "An Application of Image Processing Techniques for Detection of Diseases on Brinjal Leaves using k-Means Clustering Method", in 2016 International Conference on Recent Trends in Information Technology, ICRTIT 2016, 2016.

[18] M. Guftar, et al., "A Novel Framework for Classification of Syncope Disease using k-Means Clustering Algorithm”, in IntelliSys 2015 - Proceedings of 2015 SAI Intelligent Systems Conference, pp. 127-132, 2015.

[19] T. Santhanam and M. S. Padmavathi, "Application of K-Means and Genetic Algorithms for Dimension Reduction by Integrating SVM for Diabetes Diagnosis”, Procedia Comput. Sci., vol. 47, no. C, pp. 76-83, 2014.

[20] Y. Udovychenko, et al., "k-NN Binary Classification of Heart Failures Using Myocardial Current Density Distribution Maps", in Signal Processing Symposium (SPSympo), no. Cddm. 
[21] Y. Udovychenko, et al., "Ischemic Heart Disease Recognition by k - NN Classification of Current Density Distribution Maps", International Conference on Electronics and Nanotechnology (ELNANO), pp. 402-405, 2015.

[22] S. Saha, et al., "Gene Selection by Sample Classification Using k nearest Neighbor and Meta-heuristic Algorithms", 2016 IEEE 6th Int. Conf. Adv. Comput., pp. 250-255, 2016.

[23] S. Shah, et al., "Sentimental Analysis of Twitter Data Using Classifier Algorithms", IAES Int. J. Electr. Comput. Eng., vol. 6, no. 1, pp. 357-366, 2016.

[24] X. Wu, et al., "Top 10 Algorithms in Data Mining”, Knowl. Inf. Syst., vol. 14, pp. 1-37, 2008.

[25] F. Gorunescu, "Data Mining - Concepts, Models and Techniques", Romania, University of Craiova, 2011.

[26] I. Verma, et al., "Refined Clustering of Software Components by Using K-Mean and Neural Network," IAES Int. J. Artif. Intell., vol. 4, no. 2, pp. 62-71, 2016.

[27] K. Teknomo, "K-Means Clustering Tutorial", 2007. [Online]. Available: $\mathrm{http}: / /$ people.revoledu.com/kardi/tutorial/kMean/index.html.

[28] I. Arieshanti, et al., "Comparative Study of Bankruptcy Prediction Models," TELKOMNIKA (Telecommunication Comput. Electron. Control), vol. 11, no. 3, pp. 591-596, 2013.

[29] T. H. Saragih, et al., "Genetic Algorithm for Optimizing FIS Tsukamoto for Dental Disease Identification", in International Conference on Advanced Computer Science and Information Systems (ICACSIS), 2017.

[30] D. M. N. Fajri, et al., "Opptimized Fuzzy Neural Network for Jatropa Curcas Plant Disease Identification”, in International Conference on Sustainable Information Engineering and Technology (SIET), 2017.

\section{BIOGRAPHIES OF AUTHORS}

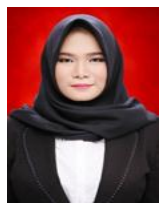

Gusti Eka Yuliastuti. She is currently as a graduate student in Faculty of Computer Science Brawijaya University, Malang, Indonesia. She obtained Bachelor Degree in Computer Science from Brawijaya University, Malang, Indonesia in 2016. Now she is currently finalizing her Master Degree in Computer Science from Brawijaya University, Malang, Indonesia. Her research fields are in Machine Learning, Artificial Intelligence, Data Mining.

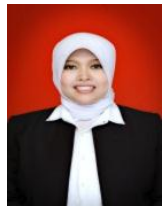

Adyan Nur Alfiyatin. She is currently as a graduate student in Faculty of Computer Science Brawijaya University, Malang, Indonesia. She obtained Bachelor Degree in Computer Science from UIN Maulana Malik Ibrahim Malang, Indonesia in 2016. Now she is currently finalizing her Master Degree in Computer Science from Brawijaya University, Malang, Indonesia. Her research fields are in Decision Support System, Optimization Method, Artificial Intelligence.

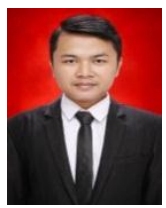

Agung Mustika Rizki. He is currently as a graduate student in Faculty of Computer Science Brawijaya University, Malang, Indonesia. He obtained Bachelor Degree in Computer Science from Brawijaya University, Malang, Indonesia in 2016. Now he is currently finalizing his Master Degree in Computer Science from Brawijaya University, Malang, Indonesia. His research fields are in Decision Support System, Optimization Method, Artificial Intelligence.

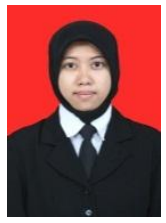

Andi Hamdianah. She is currently as a graduate student in Faculty of Computer Science Brawijaya University, Malang, Indonesia. She obtained Bachelor Degree in Computer Science from UIN Sunan Kalijaga, Yogyakarta, Indonesia in 2015. Now she is currently finalizing her Master Degree in Computer Science from Brawijaya University, Malang, Indonesia. Her research fields are in Computer Vision, Data Mining, Decision Support System, Optimization Method.

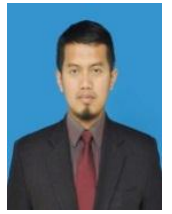

Hilman Taufiq. He is currently as a graduate student in Faculty of Computer Science Brawijaya University, Malang, Indonesia. He obtained Bachelor Degree in Microbiology from Institut Teknologi Bandung, Indonesia in 2013. Now he is currently finalizing his Master Degree in Computer Science from Brawijaya University, Malang, Indonesia. His research fields are in Optimization Method and Artificial Intelligence.

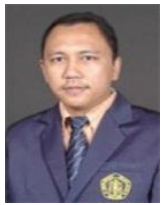

Wayan Firdaus Mahmudy. He completed his Bachelor of Mathematics education in Brawijaya University Malang, Indonesia, continued his Master of Informatics Engineering at Technology Institute November 10th Surabaya, Indonesia and obtained his Doctor of Philosophy degree from University of South Australia. He has special interest in Data Mining, Genetic Algorithms, Machine Learning, and Optimization Techniques for Manufacturing System. 